\title{
KADAR KALSIUM (Ca) DALAM CAIRAN KREVIKULAR GINGIVA PADA PENDERITA PERIODONTITIS KRONIS
}

\author{
Ita Kurniawati ${ }^{*}$ Peni Pujiastuti ${ }^{* *}$, Agustin Wulan Suci Dharmayanti ${ }^{* * *}$
}

\section{Keywords:}

gingival crevicular fluid,

calcium, periodontal

tissue, chronic

periodontitis

\begin{abstract}
Background: Chronic periodontitis occurred mostly in productive ages. Chronic periodontitis was started by adherence and accumulation of plaque bacteria that caused vascular enhancement, PMN infiltration, and periodontal tissue destruction. This process caused bone calcium solubitily which went trough blood stream and excreted to gungiva sulci. Calcium in periodontal tissue could be found both in extracellular and intracellular matrix.

Purpose: Purpose of this study was to know calcium level in gingival crevicular fluid of chronic periodontitis and compare calcium level in chronic periodontitis and gingivitis.

Method: This study was analytic observational with cross sectional approach and got admission from ethic comission of Dental Faculty, Gadjah Mada University. The subjects were patients who came to dental hospital of Jember University. The subjects had to full fill informed consent. The subjects were selected according inclusion and exclusion criteria. Subjects complying inclusion criteria were divided into gingivitis group (PI score $0-0.7$ ) and chronic periodontitis (PI score $1-8.0$ ). Gingival crevicular fluid samples were collected from teeth which got gingivitis and chronic periodontitis, GCF was absorbed using paperpoint and stored inside eppendorf tube. Paperpoint was added with $50 \mu \mathrm{L} 0.02 \mathrm{M}$ PBS $\mathrm{pH} 7.4$ and $100 \mu \mathrm{L}$ distilled water. Calcium level was measured by Atomic Absorption Spectrophotometer (AAS).

Result: The result showed there was calcium in gingival crevicular fluid of chronic periodontitis. Mean of calcium level of chronic periodontitis was higher than gingivitis.

Conclusion: This study concluded there was calcium in gingival crevicular fluid of chronic periodontitis and calcium level of chronic periodontitis was higher than gingivitis.
\end{abstract}

\section{PENDAHULUAN}

Penyakit gigi dan mulut merupakan penyakit tertinggi ke enam yang dikeluhkan masyarakat Indonesia menurut Survei Kesehatan Rumah Tangga. Ada dua penyakit gigi dan mulut yang mempunyai prevalensi cukup tinggi di Indonesia yaitu karies dan penyakit periodontal. Prevalensi penyakit periodontal sebesar $96,58 \%$ penduduk pada seluruh kelompok umur usia produktif yaitu salah satunya periodontitis kronis ${ }^{1}$.
Periodontitis kronis akan diawali dengan adanya perlekatan bakteri plak dan akumulasi bakteri plak. Akumulasi bakteri plak merupakan tahap initial lession yang akan mengakibatkan terjadinya perubahan vaskuler yang meliputi dilatasi kapiler dan peningkatan aliran darah. Setelah 7 hari, akumulasi bakteri plak akan menetap dalam waktu yang lama dan akan ada perubahan klinis berupa adanya perdarahan saat probing, tahap ini disebut early lesion. Setelah early lesion yaitu tahap established lession, secara klinis gingiva

*Dentistry Faculty Student, Faculty of Dentistry, Jember University, ${ }^{* *}$ Periodonsia Department, Faculty of Dentistry, Jember University, ${ }^{* * *}$ Biomedical Department, Faculty of Dentistry, Jember University

Email: agustinwulan.fkg@unej.ac.id 
terlihat kemerahan dan kebiruan. Selain itu, junctional epithelium dan epitel sulkus banyak terinfiltrasi oleh PMN. Setelah established lession, tahap advanced lession yaitu tahap yang biasanya terjadi periodontitis karena pada tahap ini lesi sudah mengalami kerusakan periodontal yaitu destruksi tulang. Destruksi tulang alveolar akan mengalami dua proses yaitu dekalsifikasi dan pengikisan tulang. Proses tersebut akan mengakibatkan kalsium dalam tulang mengalami kelarutan yang akan masuk ke dalam pembuluh darah. Kerusakan jaringan periodontal juga akan mempengaruhi bertambah dalamnya sulkus gingiva ${ }^{2,3}$.

Sulkus gingiva merupakan suatu celah dangkal di sekeliling gigi, sisi dalam dibatasi permukaan gigi dan sisi bagian luar dibatasi oleh epitel gingiva. Epitel sulkus gingiva berfungsi sebagai barrier biologis untuk memahami hubungan biologik komponen vaskular dan struktur periodontal. Komponen seluler dan humoral jaringan periodontal akan keluar melalui epitel tersebut bersamaan dengan cairan krevikular gingiva saat terjadi periodontitis kronis ${ }^{4}$.

Cairan krevikular gingiva merupakan cairan eksudat inflamasi yang meresap ke dalam sulkus gingiva atau poket periodontal sekitar gigi dengan keadaan inflamasi ${ }^{5}$. Hal ini menunjukkan komponen cairan krevikular gingiva meningkat dalam keadaan patofisiologis, seperti kerusakan jaringan ikat dan kerusakan tulang dan cairan krevikular gingiva memiliki nilai diagnostik. Prosedur pengambilan cairan krevikular gingiva mudah, non invasif, dan efisien untuk menjadi indikator inflamasi dan resorpsi tulang di rongga mulut $^{4}$. Saat terjadi peningkatan aliran cairan sulkus gingiva, komponen dari cairan ini juga mengalami peningkatan, salah satunya yaitu mineral kalsium yang kemungkinan berasal dari jaringan periodontal.

Kalsium dalam jaringan periodontal terdapat di dalam matriks ekstraseluler dan matriks intraseluler. Pada matriks ekstraseluler berfungsi sebagai signaling antar sel dan sumber kalsium untuk jaringan keras gigi dan periodontal. Kalsium dalam matriks intraseluler berperan sebagai mediator penyusunan aktin jaringan fibroblast dari jaringan lunak. Adanya peningkatan kalsium dalam cairan krevikular gingiva diduga disebabkan oleh kerusakan jaringan periodontal yang mana kalsium berada dalam matriks intraseluler dan ekstraseluler ${ }^{6}$. Peningkatan kalsium dari cairan krevikular gingiva berkorelasi dengan keadaan $\mathrm{pH}$ sulkus gingiva dan adanya bakteri anaerob². Adapun komponen utama dari jaringan keras gigi dan tulang alveolar yang berada pada saliva dan cairan krevikular gingiva yaitu kalsium fosfat. Saat terjadi kalsifikasi patologi dan gangguan dalam kalsium fosfat akan ada perubahan volume kalsium fosfat? Tujuan penelitian ini adalah mengetahui kadar kalsium pada penderita periodontitis kronis dan membandingkan kadar kalsium pada penderita periodontitis kronis dan gingivitis.

\section{METODE PENELITIAN}

Penelitian ini adalah observasional analitik dengan pendekatan cross sectional. Penelitian ini mendapatkan persetujuan dari komisi etik penelitian kesehatan Fakultas Kedokteran Gigi Universitas Gadjah Mada Yogyakarta. Subyek penelitian merupakan pasien yang datang di Rumah Sakit Gigi Dan Mulut Universitas Jember. Subyek penelitian harus mengisi dan menyetujui informed consent. Subyek penelitian dilakukan pemeriksaan intra oral yang meliputi menghitung jumlah gigi yang tersisa pada rongga mulut, mengukur derajat kehilangan perlekatan, perdarahan saat probing, dan kedalaman poket. Selain itu, dilakukan foto rontgen periapikal untuk mengetahui adanya resorpsi tulang alveolar. Penentuan tingkat keparahan periodontitis kronis pada individu didasarkan pada Periodontal Indeks (PI) Modifikasi Russel.

Subyek penelitian akan dipilih sesuai dengan kriteria inklusi dan eksklusi. Kriteria inklusi penelitian ini meliputi penderita berusia 35 - 45 tahun, berjenis kelamin perempuan dan laki-laki, tidak sedang hamil atau menstruasi, 
tidak menggunakan gigi tiruan, tidak memiliki kelainan sistemik dan tidak merokok. Kriteria eksklusi meliputi subyek penelitian tidak bersedia dijadikan sampel penelitian, menggunakan obat kumur, antibiotik, atau obat-obatan minimal 6 bulan terakhir dan sedang dalam perawatan periodontal 6 bulan terakhir ${ }^{8}$.

Subyek penelitian yang memenuhi kriteria inklusi akan dikelopokan menjadi kelompok gingivitis dan periodontitis kronis. Kelompok gingivitis yaitu subyek penelitian yang mempunyai skor PI 0 - 0,7; dan kelompok periodontitis yaitu subyek dengan skor PI 1 8,0 .

Pengambilan sampel cairan krevikular gingiva yaitu pada gigi yang mengalami gingivitis dan periodontitis kronis. Kriteria gigi yang mengalami gingivitis yaituada keradangan gingiva, bleeding on probing (BOP) positif, tidak ada kehilangan perlekatan, kedalamam sulkus gingiva kurang dari $3 \mathrm{~mm}$, dan pada gambaran radiografis tidak ada resorpsi tulang alveolar. Kriteria gigi yang mengalami periodontitis kronis yaitu ada keradangan gingiva, bleeding on probing (BOP) positif, ada kehilangan perlekatan, kedalamam sulkus gingiva lebih dari $3 \mathrm{~mm}$, dan pada gambaran radiografis terdapat resorpsi tulang alveolar.

Paperpoint steril yang digunakan yaitu paperpoint \#20 dengan panjang $25 \mathrm{~mm}$. Paperpoint ini diukur $20 \mathrm{~mm}$ dan diberi tanda garis dengan pensil. Tanda ini merupakan batas cairan krevikular gingiva yang terserap dan yang terserap tidak boleh melewati batas tersebut. Hal ini betujuan menyeragamkan volume cairan krevikular gingiva.
Sebelumnya dilakukan pengambilan sampel cairan crevikular gingiva, gigi tersebut dibersihkan dengan cotton roll steril untuk menghilangkan plak supragingiva. Setelah itu paperpoint dimasukkan di sulkus gingiva bagian bukal gigi yang mengalami periodontitis kronis atau gingivitis sampai cairan krevikular gingiva terserap sesuai dengan tanda garis. Kemudian paperpoint dikeluarkan dari sulkus gingiva dan dimasukkan ke dalam eppendorf tube 0,5 ml. Eppendorf tube ditutup dan diberi solatip paraffin, kemudian disimpan dalam deep freezer dengan suhu $-30^{\circ} \mathrm{C}$ sampai dilakukan uji kadar kalsium ${ }^{8}$.

Eppendorf tube tersebut dimasukkan ke dalam suhu ruang $18-25^{\circ} \mathrm{C}$. Setelah itu, disentrifugasi dengan kecepatan 2200 rpm selama 20 menit pada suhu ruang $18-25^{\circ} \mathrm{C}$. Kemudian ujung eppendorf tube dilubangi dengan jarum steril. Eppendorf tube tersebut dimasukkan ke eppendorf tube ukuran $1.5 \mathrm{~mL}$. Paperpoint kemudian diberi larutan 0,02 M PBS $\mathrm{pH} 7,4$ sebanyak $50 \mu \mathrm{L}$. Kemudian disentrifugasi dengan kecepatan 2200 rpm selama 20 menit. Larutan cairan krevikular gingiva dan PBS akan masuk ke dalam eppendorf tube ukuran $1.5 \mathrm{~mL}$. Eppendorf tube $0.5 \mathrm{~mL}$ yang berisi paperpoint dikeluarkan. Eppendorf ukuran $1.5 \mathrm{~mL}$ yang berisi larutan cairan krevikular gingiva dan PBS ditambahkan $100 \mu \mathrm{L}$ distilled water dan disentrifugasi dengan kecepatan 2200 rpm selama 20 menit. Pengukuran kadar kalsium pada GCF penderita periodontitis kronis dilakukan dengan menggunakan Atomic Absorption Spectrophotometer (AAS).

Tabel 1. Rata-rata hasil pengukuran kalsium (ppm)

\begin{tabular}{lll}
\hline \multicolumn{1}{c}{ Kelompok } & $\mathrm{N}$ & $\bar{X} \pm \mathrm{SD}$ \\
\hline Gingivitis & 13 & $2,81 \pm 1,39$ \\
Periodontitis Kronis & 13 & $4,71 \pm 0,52$ \\
\hline Keterangan: & & \\
$\bar{X} \quad$ = Rata-Rata & & \\
$\mathrm{SD} \quad$ = Simpangan Baku & & \\
$\mathrm{N} \quad$ Jumlah Sampel & &
\end{tabular}




\section{HASIL PENELITIAN}

Tabel 1 menunjukkan bahwa terdapat kadar kalsium pada penderita periodontitis kronis. Rata-rata kadar kalsium penderita periodontitis kronis lebih tinggi daripada penderita gingivitis. Hasil penelitian ini dilakukan analisis statistik Mann Whitney $U$ untuk mengetahui adanya perbedaaan ratarata kadar kalsium pada penderita periodontitis kronis dan gingivitis. Hasil uji Mann Whitney $U$ menunjukkan terdapat perbedaan yang signifikan pada rata-rata kadar kalsium penderita periodontitis kronis dengan gingivitis $(p \leq 0,05)$ (tabel 2).

Tabel 2. Hasil Uji Mann-Whitney

\begin{tabular}{|c|c|c|}
\hline & Mann-Whitney U & Sig \\
\hline $\begin{array}{l}\text { Gingivitis } \\
\text { Periodontitis }\end{array}$ & 15,000 & 0,00 * \\
\hline
\end{tabular}

\section{DISKUSI}

Hasil penelitian menunjukkan terdapat kalsium dalam cairan krevikular gingiva pada penderita periodontitis kronis. Hal ini kemungkinan disebabkan kerusakan jaringan periodontal pada periodontitis mengakibatkan kelarutan kalsium dalam jaringan periodontal dan keluar bersamaan dengan cairan krevikular gingiva. Reddy dkk menunjukkan bahwa mineral-mineral pada jaringan periodontal akan terlarut bersamaan dengan cairan krevikular gingiva oleh karena adanya demineralisasi jaringan periodontal dan kerusakan jaringan periodontal akibat adanya keradangan jaringan periodontal ${ }^{2}$. Mineralmineral yang terlarut tersebut kemungkinan salah satunya adalah kalsium.

Hasil penelitian juga menunjukkan bahwa kalsium pada penderita periodontitis kronis lebih tinggi dibanding penderita gingivitis, serta terdapat perbedaan yang signifikan ratarata kadar kalsium pada cairan krevikular gingiva penderita gingivitis dan periodontitis kronis. Hal ini kemungkinan disebabkan pada penderita gingivitis, kalsium yang terlarut berasal dari kalsium jaringan gingiva, sedangkan pada penderita periodontitis kronis berasal dari seluruh jaringan periodontal yaitu gingiva, sementum, ligament periodontal, dan tulang alveolar. Kalsium pada jaringan periodontal kemungkinan terdapat di intrasel fibroblas dan ekstraseluler jaringan periodontal. An, dkk menyatakan bahwa kalsium terdapat di intrasel dan ekstraseluler fibroblas yang keduanya saling bereaksi melalui calcium sensing reseptor untuk menentukan perilaku sel dan menginduksi proliferasi serta diferensiasi sel $^{9}$. Fibroblas merupakan sel penyusun utama jaringan periodontal kecuali sementum².

Selain itu, kelarutan kalsium pada cairan krevikular gingiva kemungkinan disebabkan oleh peningkatan cairan sulkus gingiva. Aliran cairan krevikular gingiva meningkat pada keadaan keradangan, semakin parah keradangan maka aliran cairan krevikular gingiva semakin meningkat. Cairan krevikular gingiva merupakan cairan yang berasal dari pembuluh darah gingiva yang melalui epithelium junctional ke sulkus gingiva. Pada sulkus yang sehat, volume cairan krevikular gingiva sangat sedikit. Keradangan akan meningkatkan pembuluh darah dibawah epitel suklus gingiva dan junctional yang merupakan epitel penyusun sulkus gingiva. Peningkatan volume cairan krevikular gingiva tersebut juga berhubungan dengan peningkatan permeabilitas pembuluh darah pada gingiva. Saat inflamasi akan terjadi pembesaran ruang antara junctional dan sulcular epithelium. Pembesaran ruang ini yang menyebabkan komponen cairan krevikular gingiva yang salah satunya kalsium akan mudah masuk yang nantinya akan larut bersama aliran darah dan dikeluarkan melalui sulcular epithelium ${ }^{2}$. Dengan adanya peningkatan tersebut filtratfiltrat yang meliputi mineral, hasil metabolisme bakteri akan keluar karena limfatik yang berkurang, permeabilitas menigkat,dan adanya tekanan osmotik sehingga kalsium akan keluar melalui cairan krevikular gingiva ${ }^{10}$. 
Kalsium merupakan ion penting untuk melihat kerusakan jaringan periodontal. Kalsium berfungsi untuk mengontrol proses seluler seperti fertilisasi, mitosis, dan kematian sel. Kematian sel pada ligamen periodontal dapat meningkatkan konsentrasi ion kalsium dan juga memicu mineralisasi ligamen periodontal dan kematian sel, sehingga kalsium dapat digunakan untuk menandakan adanya kerusakan jaringan periodontal ${ }^{6}$.

Pada penelitian ini tidak dapat membedakan kalsium apakah berasal dari jaringan periodontal atau kalkulus karena saat dilakukan penelitian tidak menghilangkan kalkulus. Kemungkinan kalsium pada cairan krevikular gingiva bisa berasal dari kalkulus atau jaringan periodontal yang mengalami kerusakan. Akan tetapi, peneliti berkeyakinan bahwa kalsium pada penelitian ini sebagian besar berasal dari jaringan periodontal yang mengalami kerusakan. Hipotesa ini didukung oleh kadar $\mathrm{pH}$ cairan krevikular gingiva yang menunjukkan $\mathrm{pH}$ basa yaitu $7.4^{11}$. John dkk menyatakan bahwa lingkungan sulkus gingiva manusia pada keadaan normal $\mathrm{pH}$ sedikit asam yaitu 6,7, kemudian dalam keadaan terinflamasi pada linkungan disekitar jaringan periodontal yaitu sulkus gingiva cenderung basa karena berhubungan dengan katabolisme, pelepasan amonia, dan hasil metabolisme bakteri subgingiva gram negatif. Dalam keadaan basa ini akan menyebabkan kerusakan jaringan periodontal dan terlarutnya mineral-mineral lain ${ }^{12}$. Perubahan $\mathrm{pH}$ basa pada cairan krevikular gingiva ini disebabkan adanya peningkatan kadar urea pada cairan krevikular gingiva dengan keadaan $\mathrm{pH}$ rendah menjadi normal dan $\mathrm{pH}$ akan menjadi basa disebabkan oleh adanya toksik dan enzim yang diproduksi oleh bakteri Porphyromonas gingivalis. Saat keadaan $\mathrm{pH}$ menjadi basa, hal ini menandakan adanya destruksi jaringan periodontal. Sedangkan, Tamilyanan menyatakan pembentukan kalkulus akan melibatkan bakteri acidogenic yaitu bakteri yang mengeluarkan asam, sedangkan $\mathrm{pH}$ cairan krevikular gingiva pada pembentukan kalkulus yaitu asam ${ }^{13}$.

\section{KESIMPULAN}

Penelitian ini menunjukkan bahwa terdapat kalsium pada cairan krevikular gingiva penderita periodontitis kronis, dan kalsium pada cairan krevikular gingiva penderita periodontitis kronis lebih tinggi dari pada gingivitis. Kadar kalsium pada cairan krevikular gingiva ini dapat digunakan sebagai indikator keparahan penyakit jaringan periodontal.

\section{DAFTAR PUSTAKA}

1. Situmorang N. Profil penyakit periodontal penduduk di dua kecamatan kota Medan tahun 2004 dibandingkan dengan kesehatan mulut tahun 2010 WHO. Dentika Dental J 2003; 9 (2): 71-77.

2. Reddy S. Essentials of Clinical Periodontology and Periodontics. 4th Edition. Jaypee. New Delhi. 2008.

3. Newman, M. G., Takei, H. H., dan Carranza, F. A. Carranza's Clinical Peridontology. Ninth Edition. Philadelphia. 2002

4. Delima, A J., Thomas E. Van Dyke. Origin and Function of The Cellular Components in Gingival Crevice Fluid. Periodontol 2000 2003, 31: 55-76.

5. Armitage G.C. Analysis of Gingival Crevice Fluid and Risk of Progression of Periodontitis. Journal Periodontol 2000 2004, 34 (1): 109-19

6. Ko KS, Arora PD, Bhide V, Chen A, McCulloch CA. Cell-cell adhesion in human fibroblasts requires calcium signaling. J Cell Sci. 2001, 114(Pt 6): 115567.

7. Kolahi J, Mahdi Shahmoradi, Molood Sadreshkevary. Nanobacteria in clouds can spread oral pathologic calcifications around the world. Dental Hypotheses 2012, 3 (4): 138-141

8. Suci-Dharmayanti, A W. Deoxypyridinoline level in gingival crevicular fluid as alveolar bone loss biomarker in periodontal disease. Dental Journal 2012, 45 (2): 102-106

9. An S, Ling J, Gao Y, Xiao Y. Effects of varied ionic calcium and phosphate on the proliferation, osteogenic differentiation and mineralization of human periodontal ligament cells in vitro. Journal of Periodontal Research 2012, 17 (3): 374-382

10. Bhardwaj S, Munivenkattapa Laksmalah, Venkatesh Prabhuji. Comparative Volumetric and Clinical Cualution of Peri Implant Sulcular Fluid and Gingiva Crevicular Fluid. J Periodontal Implant Sci. 2013 Oct; 43(5): 233-242.

11. Suci-Dharmayanti, AW. Identifikasi Kadar Deoksipiridinolin dalam Cairan Krevikular Gingiva sebagai Parameter Kerusakan Tulang Penderita Periodontitis Disertai Osteoporosis. Laporan Dosen 
Pemula. Lembaga Penelitian Universitas Jember. 2014.

12. Leblebicioglu B, Walters J. Alkaline Conditions Accelerate Polymorphonuclear Leukocyte Apoptosis in Vitro. Infect Immun 1999, 67 (4): 2019-2021.

13. Shunmugaperumal T. Biofilm Eradication and Prevention: A Pharmaceutical Approach to Medical Device Infections. New York. John Wiley \& Sons, Inc. 2010. 